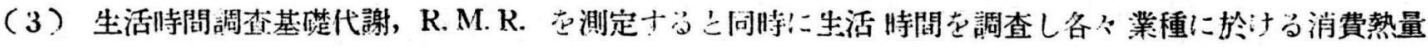

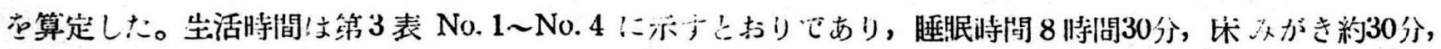

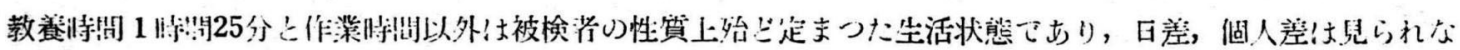
i。

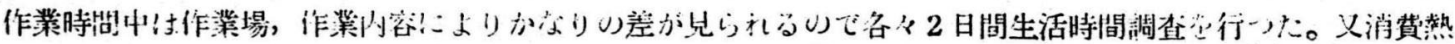

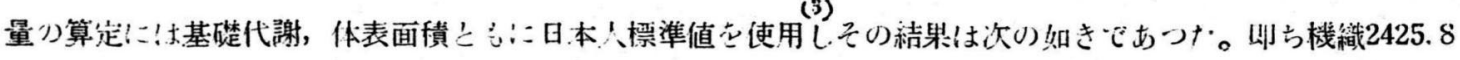

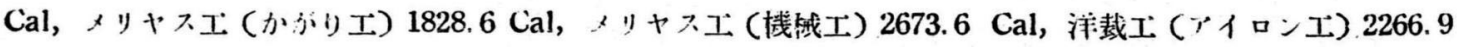
Cal であうた。

[小括] $\mathrm{F}$ 刑務所!二収容中心健康男子受刑者20名》基璴代謝，及心彼等の従事している各職㮔のR. M. R. 苍測

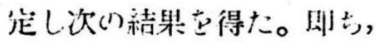

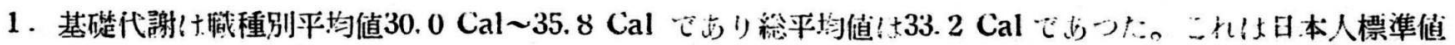

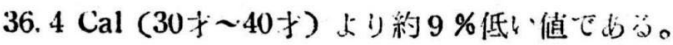

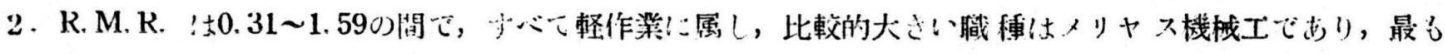

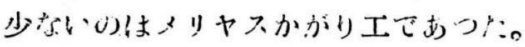

3. 消費熱量! $1829 \mathrm{Cal} \sim 2674 \mathrm{Cal}$ 心間てあった。

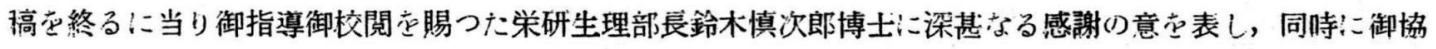

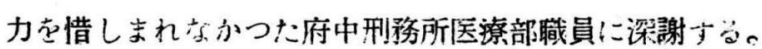

\title{
女 献
}

鈴木慎次郎 : 労動のエネルギー原則 (1948)

甲賀 正荄：矯正医学 2,1 (1953)

日本人の栄養所要量に関方解説 総理府資源調查会 (1954)

第 13 尜 第 $5 \cdot 6$ 号正譟表

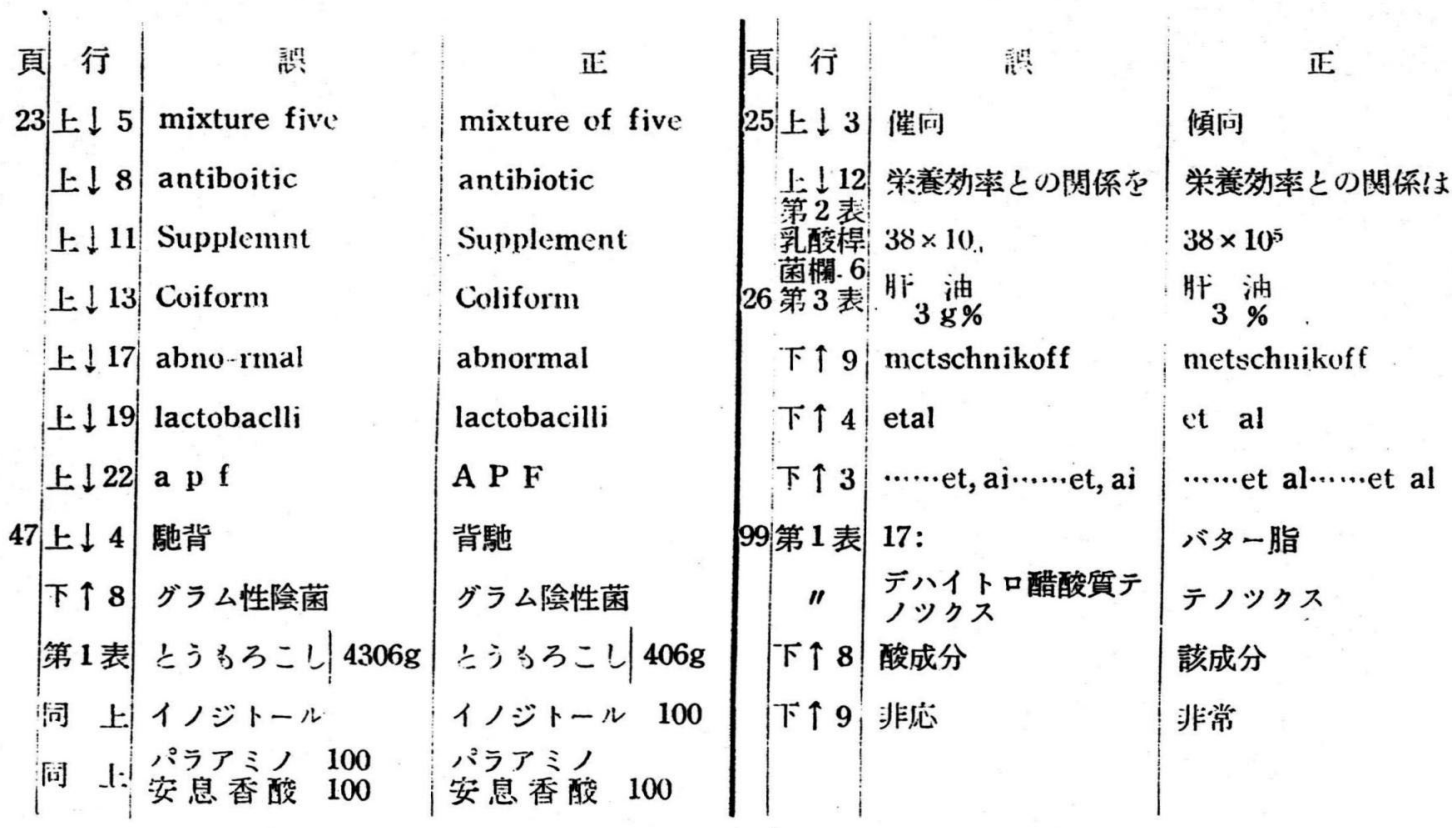

